IJIS Indonesian Journal on Information System

\title{
SISTEM PENGOLAHAN DATA REKAM MEDIS BERBASIS WEB PADA PUSKESMAS PERAWATAN JAMBULA KOTA TERNATE
}

\section{DATA PROCESSING SYSTEM WEB-BASED MEDICAL RECORD IN THE HEALTH CARE JAMBULA TERNATE CITY}

\author{
Kausar arif ${ }^{1}$, Arisandy Ambarita ${ }^{2}$ \\ Program Studi Manajemen Informatika, \\ Politeknik Sains dan Teknologi Wiratama Maluku Utara \\ kausararif@gmail.com
}

\begin{abstract}
Abstrak
Perkembangan teknologi informasi sangat mempengaruhi berbagai segi kehidupan dan profesi. salah satunya pada bidang pelayanan Kesehatan. Di setiap tempat layanan kesehatan setiap ada pasien yang datang untuk berobat maka akan dicatat baik identitas pasien, hasil diagnosa penyakit oleh dokter, obat yang diberikan kepada pasien, serta tindakan lain yang dilakukan oleh dokter terhadap pasien yang biasa disebut dengan Rekam Medis. Puskesmas Perawatan Jambula merupakan salah satu pusat pelayanan kesehatan masyarakat yang terletak di desa Jambula kota ternate, dimana sistem pelayanan dan pengelolaan data rekam medis masih bersifat konvensional dimana petugas medis yang ada pada Puskesmas melakukan pencatatan data-data pasien secara tertulis dan diproses pada buku besar, sehingga sering terjadi kesalahan dalam pencatatan. Peniltian ini dilakukan pada Puskesmas Perawatan Jambula bertujuan memberikan kemudahan kepada petugas medis dalam megelola dan menyimpan data rekam medis pasien yang tadinya masih di lakukan secara konvesional, pengumpulan data diperoleh melalui observasi, wawancara, dokumentasi, Analisis, Perancangan dan Implementasi, Sistem yang di rancang diharapkan dapat mengurangi tingkat kesalahan pada proses pencatatan data pasien secara manual.
\end{abstract}

\section{Kata Kunci : Sistem, Pengolahan Data, Rekam medis}

\begin{abstract}
The development of information technology is affecting various aspects of life and profession. one of them in the health care field. In each health service, every patient who comes for treatment will be recorded in both the identity of the patient, the diagnosis of disease by doctors, drugs given to patients, as well as other actions carried out by doctors to patients is commonly called the Medical Record. PHC Care Jambula is one of the community health service centers are located in the village Jambula city of Ternate, where the system of care and management of medical records is still conventional in which medical personnel are there at health centers keep records of patient data in written and processed on a ledger, so frequent errors in recording. These studies were conducted at PHC Care Jambula aims to provide convenience to the medical staff in megelola and storing medical records of patients who had still done in conventional, collection of data obtained through observation, interviews, documentation, Analysis, Design and Implementation, Systems are designed expected can reduce the error rate in the process of recording patient data manually.
\end{abstract}

Keyword: Systems, Data Processing, Medical Record 


\section{PENDAHULUAN}

Perkembangan teknologi informasi sekarang ini mempengaruhi berbagai segi kehidupan dan profesi. salah satunya pada bidang pelayanan Kesehatan. Di setiap tempat layanan kesehatan setiap ada pasien yang datang untuk berobat maka akan dicatat baik identitas pasien, hasil diagnosa penyakit oleh dokter, obat yang diberikan kepada pasien, serta tindakan lain yang dilakukan oleh dokter terhadap pasien yang biasa disebut dengan Rekam Medis. Dimana data Rekam Medis akan digunakan sebagai acuan untuk pengobatan pasien pada pemeriksaan berikutnya

Pencatatan data riwayat kesehatan pasien adalah hal yang penting dalam dunia medis dan dikenal dengan istilah data rekam medis. Selama pasien melakukan pemeriksaan atau menjalani perawatan medis oleh dokter atau suatu instansi medis, maka status kesehatan pasien akan dicatat sebagai data rekam medis pasien. Data rekam medis pasien tersebut dapat dipakai sebagai acuan untuk pemeriksaan kesehatan pasien selanjutnya, sekaligus sebagai bukti tercatat mengenai diagnosis penyakit pasien dan pelayanan medis yang diperoleh pasien (Suhadi, 2007:1).)

Di dalam Peraturan Menteri Kesehatan (Permenkes) Nomor 749a tahun 1989 disebutkan bahwa setiap sarana pelayanan kesehatan wajib menyelenggarakan Rekam Medis. Rekam Medis adalah berkas yang berisikan catatan dan dokumen tentang identitas pasien, pemeriksaan, pengobatan, tindakan dan pelayanan lain kepada pasien pada sarana pelayanan kesehatan. Rekam Medis mempunyai tujuan untuk menunjang tercapainya tertib administrasi dalam rangka upaya peningkatan pelayanan kesehatan di rumah sakit. Penyelenggaraan Rekam Medis di rumah sakit meliputi penerimaan pasien, pelayanan medis dan keperawatan, pelayanan administrasi dan keuangan, pencatatan data Rekam Medis dan pelaporan.

Puskesmas Perawatan Jambula merupakan salah satu pusat pelayanan kesehatan masyarakat yang terletak di desa Jambula kota ternate, dimana sistem pelayanan dan pengelolaan data rekam medis masih bersifat konvensional dimana petugas medis yang ada pada Puskesmas melakukan pencatatan data-data pasien secara tertulis dan diproses pada buku besar, sehingga sering terjadi kesalahan dalam pencatatan dan pada proses penyimpanan data-data pasien yang sebelumnya di berikan dari rumah sakit yang terdapat arsip-arsip dapat menyulitkan petugas medis dalam melakukan pencarian data tersebut

Dengan melihat masalah yang di hadapi oleh Puskesmas perawatan Jambula Kota Ternate, maka peneliti merancang Sistem Pengolahan Data Rekam Medis Berbasis Web, untuk memberikan kemudahan petugas medis dalam megelola dan menyimpan data rekam medis pasien yang tadinya masih di lakukan secara konvesional sebelumnya

\section{Rumusan Masalah}

Masalah dalam penilitian ini adalah Bagaimana merancang Sistem Pengolahan Data rekam medis berbasis web pada Puskesmas Perawatan Jambula? penilitian ini bertujuan untuk merancang Sistem Pengolahan Data rekam medis Berbasis Web untuk mempermudah petugas medis dalam mengelola dan menyimpan Data rekam medis secara akurat dan efesien

\section{LANDASAN TEORI}

\section{Defenisi Sistem Informasi}

Sistem Informasi didefinisikan secara teknis sebagai satuan komponen yang 
saling berhubungan yang mengumpulkan (atau mendapat kembali), memroses, menyimpan, dan mendistribusikan informasi untuk mendukung pengambilan keputusan dan kendali dalam suatu organisasi. Sebagai tambahan terhadap pendukung pengambilan keputusan, kordinasi, dan kendali, sistem informasi juga dapat membantu para manajer dan karyawan untuk meneliti permasalahan, memvisualisasikan pokok-pokok yang kompleks, dan menciptakan produkproduk baru. (Laudon $(2005,9)$

Tugas dari sistem informasi adalah untuk melakukan siklus pengolahan data. Untuk melakukan siklus ini, maka sebagai suatu sistem diperlukan komponen komponen tertentu. Telah diketahui bahwa data perlu diolah untuk dijadikan informasi yang berguna lewat suatu siklus. Siklus ini disebut siklus pengolahan data atau disebut juga dengan nama siklus informasi (Jogiyanto, 2009).

\section{Pengertian Data}

Menurut Fathansyah (2007:12), data fakta atau bagian dari fakta yang mengandung arti yang dihubungkan dengan kenyataan, simbol-simbol yang menunjukan suatu ide, atau situasi dan lain-lain. Menurut Sondang Siagian (2006:118), data merupakan bahan mentah atau bahan baku yang telah diolah lebih lanjut bentuknya menjadi informasi. Dari pengertian tersebut dapat disimpulkan bahwa data adalah sekumpulan bahan baku dapat berupa, simbol-simbol, angka, maupun huruf dalam bentuk satu kesatuan yang dapat diolah menjadi sebuah informasi.

\section{Pengertian Pengolahan Data}

Menurut John Longkutoy (2003:328), pengolahan data adalah segala macam pengolahan terhadap data atau kombinasi dari macam-macam pengolahan data untuk membuat data itu berguna sesuai dengan hasil yang diinginkan, sehingga dapat dipakai.

Menurut Sondang Siagian (2006:81), pengolahan data secara elektronik merupakan suatu rangkaian kegiatan yang dimaksud untuk mengeluarkan informasi dengan menggunakan komputer yang mencakup pengumpulan, pemrosesan, dan penyimpanan hasil olahan data. Dari uraian di atas dapat disimpulkan bahwa pengolahan data adalah proses pengumpulan, penyimpanan dan pengawasan sehingga menjadi suatu informasi yang berbentuk data dan fakta

\section{Pengertian Rekam Medis}

Menurut Permenkes No. 749a/ Menkes/ Per/ XII/ 1989: "Rekam Medis adalah berkas yang berisikan catatan dan dokumen tentang identitas pasien, pemeriksaan, pengobatan, tindakan dan pelayanan lain (yang diberikan) kepada pasien (yang dipergunakan) pada sarana pelayanan kesehatan" (Anomimouse.c.2015).

Rekam medis (RM) merupakan salah satu sumber informasi sekaligus sarana komunikasi yang dibutuhkan baik oleh penderita, maupun pemberi pelayanan kesehatan, untuk pertimbangan dalam menentukan suatu kebijakan tata laksana/pengelolaan atau tindakan medic

\section{Komponen Sistem Informasi}

Komponen - komponen sistem informasi adalah sebagai berikut:

1. Blok Masukan (Input Block)

Input mewakili data yang masuk ke dalam sistem informasi. Input disini termasuk metode-metode dan media untuk menangkap data yang akan 
dimasukkan dapat berupa dokumendokumen dasar.

2. Blok Model (Model Block)

Blok ini terdiri dari kombinasi prosedur, logika dan model matematika yang akan memanipulasi data input dan data yang tersimpan di basis data dengan cara tertentu untuk menghasilkan keluaran yang diinginkan.

3. Blok Keluaran (Output Block)

Keluaran yang merupakan informasi yang berkualitas dan dokumentasi yang berguna untuk semua tingkatan manajemen serta pemakai sistem.

4. Teknologi digunakan untuk menerima input, menjalankan model, menyimpan dan mengakses data, menghasilkan, mengirimkan keluaran dan membantu pengendalian dari sistem secara keseluruhan.

5. Blok Basis Data (Database Block)

Basis Data merupakan kumpulan dari data yang saling berhubungan satu dengan yang lainnya, tersimpan di perangkat keras komputer dan menggunakan perangkat lunak untuk memanipulasinya. Basis data diakses atau dimanipulasi dengan menggunakan perangkat lunak paket yang disebut dengan DBMS (Database Management System).

6. Blok Kendali (Controls Block)

Pengendali perlu dirancang dan diterapkan untuk meyakinkan bahwa hal-hal yang dapat merusak sistem dapat dicegah ataupun bila terlanjur terjadi kesalahan maka dapat langsung diatasi dengan cepat

\section{Pengertian Puskesmas}

Puskesmas adalah organisasi fungsional yang menyelenggarakan upaya kesehatan yang bersifat menyeluruh, terpadu, merata, dapat diterima dan terjangkau oleh masyarakat, dengan peran serta aktif masyarakat dan menggunakan hasil pengembangan ilmu pengetahuan dan teknologi tepat guna, dengan biaya yang dapat dipikul oleh pemerintah dan masyarakat.

Menurut Depkes RI (1991) "Puskesmas adalah suatu kesatuan organisasi fungsional yang berlaku sebagai pusat pengembangan kesehatan masyarakat, Puskesmas dapat memberikan pelayanan rawat inap selain pelayanan rawat jalan. Hal ini disepakati oleh puskesmas dan dinas kesehatan yang bersangkutan. Perawat memberikan pelayanan di masyarakat, puskesmas biasanya memiliki sub unit pelayanan seperti puskesmas pembantu, puskesmas keliling, posyandu, pos kesehatan desa maupun pos bersalin desa (polindes).

\section{Pengertian Perawatan}

Menurut Vincent Gasper "Perawatan" ( maintenance ) merupakan suatu kegiatan yang diarahkan pada tujuan untuk menjamin kelangsungan fungsional suatu sistem produksi sehingga dari sistem produksi sehingga dari sistem itu dapat diharapkan menghasilkan out put sesuai dengan yang dikehendaki. (Anomimouse.d.2015)

Perawatan adalah pelayanan profesioanl yang merupakan bagian integral dari pelayanan kesehatan berdasarkan ilmu dan kiat keperawatan, berbentuk pelayanan biopsikososial spiritual yang menyeluruh ditujukan kepada individu, kelompok dan masyarakat baik sehat maupun sakit yang mencakup seluruh proses kehidupan manusia. 
Secara umum perawatan mempunyai tujuan-tujuan yang menurut A. S Corder adalah sebagai berikut :

1. Memungkinkan tercapainya mutu produksi dan kepuasan pelanggan melalui penyesuaian, pelayanan dan pengoperasian peralatan secara tepat .

2. Memaksimalkan umur kegunaan dari sistem .

3. Menjaga agar sistem aman dan mencegah berkembangnya gangguan keamanan

4. Meminimalkan biaya produksi total yang secara langsung dapat dihubungkan dengan service dan perbaikan

5. Memaksimalkan produksi dari sumber- sumber sistem yang ada .

6. Meminimalkan frekuensi dan kuatnya gangguan terhadap proses operasi.

7. Menyiapkan personel, fasilitas dan metodenya .

8. Agar mampu mengerjakan tugas-tugas perawatan

\section{Rawat Jalan}

Rawat Jalan dibedakan menjadi :

a. Rawat Jalan tingkat pertama adalah pelayanan kesehatan perorangan yang bersifat umum dan dilaksanakan pada pemberi pelayanan kesehatan tingkat pertama untuk keperluan observasi, diaagnosis, pengobatan, dan/atau pelayanan kesehatan lainnya.

b. Rawat Jalan tingkat lanjutan adalah pelayanan kesehatan perorangan yang bersifat spesialistik atau sub spesialistik dan dilaksanakan pada pemberi pelayanan kesehatan tingkat lanjutan sebagai rujukandari pemberi pelayanan kesehatan tingkat pertama, untuk keperluan observasi, diagnosis, pengobatan rehabilitasi medis, dan/atau pelayanan medis lainnya termasuk konsultasi psikologi tanpa menginap diruang perawatan. (PERMENKES RI NO. 029 TAHUN 2012)

\section{Rawat Inap}

Rawat Inap dibedakan menjadi:

a. Rawat Inap tingkat pertama adalah pelayanan kesehatan perorangan yang bersifat umum dilaksanakan pada Puskesmas perawatan, untuk keperluan observasi, perawatan, diagnosis, pengobatan, dan/atau pelayanan medis lainnya, dimana peserta dan/atau anggota keluarganya dirawat inap paling singkat 1 (satu) hari.

b. Rawat Inap tingkat lanjutan adalah pelayanan kesehatan perorangan yang bersifat spesialistik atau sub spesialistik untuk keperluan observasi, perawatan, diagnosis, pengobatan, rehabilitasi medis dan/atau pelayanan medis lainnya termasuk konsultasi psikologi, yang dilaksanakan pada pemberi pelayanan kesehatan tingkat lanjutan dimana peserta atau anggota keluarganya dirawat inap di ruang perawatan paling singkat 1 (satu) hari. (PERMENKES RI NO. 029 TAHUN 2012)

\section{Konsep Pemodelan Sistem}

\section{Flowchart}

Flowchart adalah bagan-bagan yang mempunyai arus yang menggambarkan langkah-langkah penyelesaian suatu masalah. penggambaran secara grafik dari langkah-langkah dan urut-urutan prosedur dari suatu program. Flowchart menolong analis dan programmer untuk memecahkan masalah kedalam segmen-segmen yang lebih kecil dan menolong dalam 
menganalisis alternatif-alternatif lain dalam pengoperasian

\section{Diagram Konteks}

Diagram Konteks atau DAD merupakan proses mentranformasi data, aliran data yang menggerakkan data, objek yang memproduksi serta mengonsumsi data, serta data store yang menjadi tempat penyimpanan data. (Imam Haryanto : 2007)

\section{Data Flow Diagram}

Menurut Andri Kristanto (2003:55), Data Flow Diagram (DFD) adalah suatu model logika data atau proses yang dibuat untuk menggambarkan dari mana asal data dan kemana tujuan data yang keluar dari sistem, dimana data disimpan, proses apa yang menghasilkan data tersebut dan interaksi antara data disimpan dan proses yang dikenakan pada data tersebut.

\section{Entity Relationship Diagram (ERD)}

Entity Relationship Diagram merupakan gambaran sistematis model data yang berisi himpunan entitas dan himpunan relasi yang masing-masing dilengkapi dengan atribut-atribut yang mempresentasikan seluruh fakta

\section{METODE PENELITIAN}

\section{Teknik Pengumpulan Data}

1) Interview adalah Suatu metode pengumpulan data dengan cara tanya jawab atau wawancara secara langsung kepada Pegawai dan StafStaf pada Puskesmas Jambula.

2) Observasi adalah Suatu metode pengumpulan data dimana penelitian dilakukan secara langsung terhadap objek yang akan diteliti, melihat serta mempelajari permasalahan yang ada dilapangan yang erat kaitannya dengan objek yang diteliti yaitu informasi pelayanan pasien.
3) Kepustakaan adalah suatu metode pengumpulan data melalui buku dan internet yang digunakan dalam penyusunan penilitian ini.

\section{Bahan dan Alat Penelitian}

Bahan yang digunakan dalam penelitian ini adalah, software dan hardware.

a. Software yang dipakai adalah :

1. Sistem Operasi Windows 7 ultimate

2. Microsoft Visio 2007 untuk membuat flowchart

3. Notepad++

4. Web Server XAMPP (Apache, MySQL)

5. Bahasa pemograman HTML, PHP, dan CSS

b. Hardware yang digunakan dalam penelitian adalah seperangkat personal computer (PC) dengan spesifikasi, sebagai berikut :

1. Processor Intel Celeron CPU B815 $(1.60 \mathrm{GHz})$

2. Intel HD Graphics

3. LCD LED HD 14.0"

4. Mainboard Intel.

5. RAM 2 GB DDR3

6. Hardisk $320 \mathrm{~GB}$.

7. Mouse Optik

8. Keyboard

9. Printer Canon Pixma MP237

\section{Analisa sistem yang berjalan}

Sistem yang berjalan merupakan sistem yang masih kovensional dalam mengelola data rekam medis pada Puskesmas Jambula kota ternate, Berdasarkan analisis yang dilakukan berikut gambar alur sistem yang berjalan 
username dan password. Dapat di lihat pada Tabel admin berikut

Tabel 1: Admin

\begin{tabular}{|l|l|c|c|}
\hline Name & Type & Length & $\begin{array}{l}\text { Auto_Increm } \\
\text { ent }\end{array}$ \\
\hline Id & int & 11 & $*$ \\
\hline username & $\begin{array}{l}\text { varcha } \\
\mathrm{r}\end{array}$ & 6 & \\
\hline password & $\begin{array}{l}\text { varcha } \\
\mathrm{r}\end{array}$ & 6 & \\
\hline $\begin{array}{l}\text { Leve } \\
1\end{array}$ & $\begin{array}{l}\text { varcha } \\
\mathrm{r}\end{array}$ & 1 & \\
\hline
\end{tabular}

Gambar 1 : Flowchart Sistem Yang Berjalan

\section{Rancangan system yang di usulkan}

Sistem yang di usulkan merupakan sistem yang baru untuk mengganti sistem yang masih konvensional dalam pengolahan data Rekam Medis, berikut alur rancangan sistem yang di usulkan

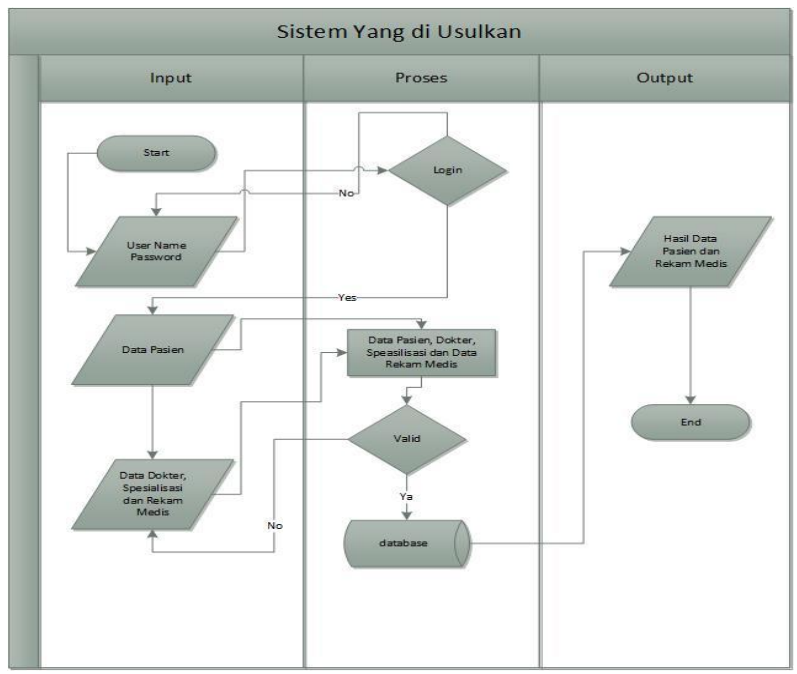

Gambar 2 : Flowchart Sistem Yang Diusulkan

\section{PERANCANGAN SISTEM}

Perancangan Tabel

a. Tabel admin (tbl_Admin)

Tabel Admin digunakan untuk menyimpan data dari admin seperti id b. Tabel Data Dokter (tbl_Dokter)

Tabel data dokter digunakan untuk menyimpan data dokter. Dapat di lihat pada Tabel dokter berikut:

Tabel 2 : Dokter

\begin{tabular}{|l|l|c|c|}
\hline Name & Type & Length & $\begin{array}{l}\text { Auto_Incre } \\
\text { ment }\end{array}$ \\
\hline id & Int & 5 & $*$ \\
\hline Nama & $\begin{array}{l}\text { Varch } \\
\text { ar }\end{array}$ & 50 & \\
\hline $\begin{array}{l}\text { Tbl_speciali } \\
\text { st_nama_id }\end{array}$ & Int & 5 & \\
\hline
\end{tabular}

\section{c. Tabel Spesialisasi}

Tabel Spesialisasi digunakan untuk menyimpan data dokter berdasarkan keahliannya. Dapat di lihat pada Tabel Spesialisasi berikut:

Tabel 3 : Spesialisasi

\begin{tabular}{|l|l|c|l|}
\hline Name & Type & $\begin{array}{l}\text { Lengt } \\
\text { h }\end{array}$ & $\begin{array}{l}\text { Auto_Increme } \\
\text { nt }\end{array}$ \\
\hline Id & int & 5 & \\
\hline Nama & $\begin{array}{l}\text { Varch } \\
\text { ar }\end{array}$ & 50 & \\
\hline
\end{tabular}

\section{d. Tabel Pasien (tbl_Pasien)}

Tabel pasien digunakan untuk menyimpan data pasien yang masuk. Dapat di lihat pada Tabel Spesialisasi berikut : 
Tabel 4 : Pasien

\begin{tabular}{|c|c|c|c|}
\hline Name & Type & $\begin{array}{l}\text { Lengt } \\
\mathrm{h}\end{array}$ & $\begin{array}{l}\text { Auto_Increm } \\
\text { ent }\end{array}$ \\
\hline $\mathrm{Id}$ & int & 11 & $*$ \\
\hline Nama & $\begin{array}{c}\text { varcha } \\
\mathrm{r}\end{array}$ & 30 & \\
\hline Alamat & $\begin{array}{c}\text { Varcha } \\
\mathrm{r} \\
\end{array}$ & 225 & \\
\hline $\begin{array}{l}\text { Tanggal_la } \\
\text { hir }\end{array}$ & Date & 8 & \\
\hline $\begin{array}{l}\text { Jenis_kela } \\
\text { min }\end{array}$ & $\begin{array}{c}\text { Varcha } \\
\mathrm{r}\end{array}$ & 1 & \\
\hline $\begin{array}{l}\text { Golongan_ } \\
\text { darah }\end{array}$ & $\begin{array}{l}\text { Varcha } \\
\mathrm{r}\end{array}$ & 1 & \\
\hline $\begin{array}{l}\text { Tbl_kartu_ } \\
\text { sehat_nam } \\
\text { a_id }\end{array}$ & Int & 2 & \\
\hline
\end{tabular}

Diagram Konteks

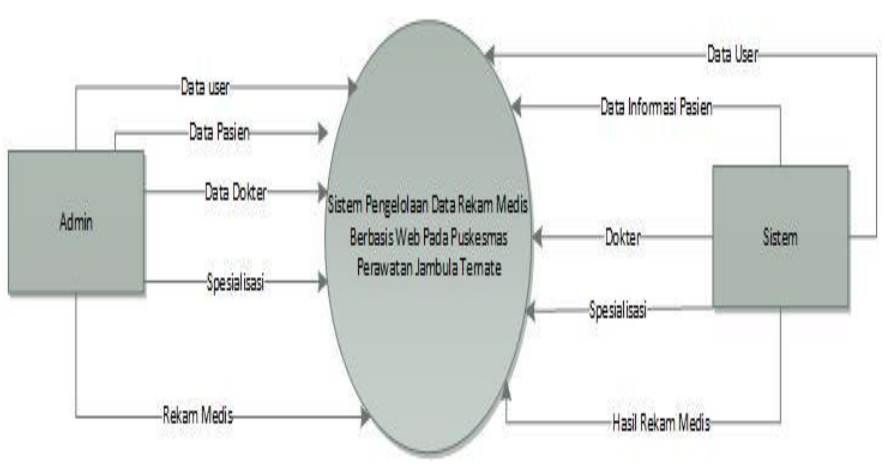

Gambar 3 : Diagram Konteks Sistem

Pengolahan Data Rekam Medis

\section{DFD Level 1}

Diagram konteks adalah gambaran sistem secara keseluruhan, hanya berisi satu proses yang menggambarkan sistem tersebut terhubung dengan entitas eksternal. Diagram konteks dari perancangan sistem dapat dilihat pada gambar sebagai berikut:

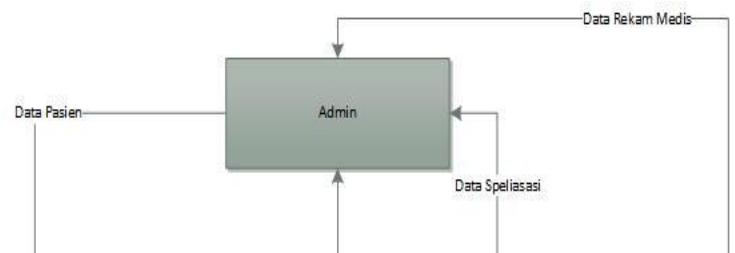

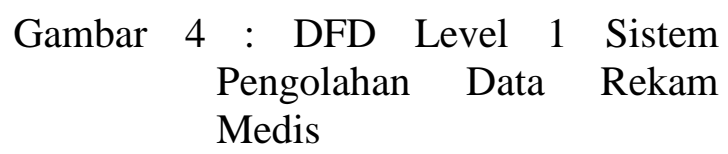

\section{ERD (entity relationship diagram)}

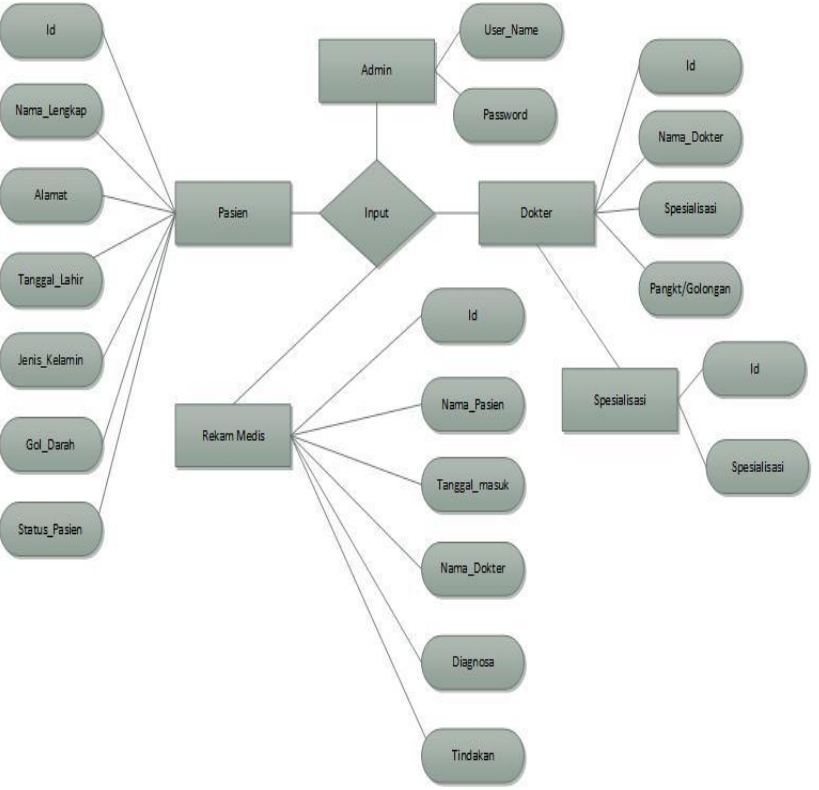

Gambar 5:ERD Sistem Pengolahan Data Rekam Medis

\section{IMPLEMENTASI SISTEM}

\section{Form Admin}

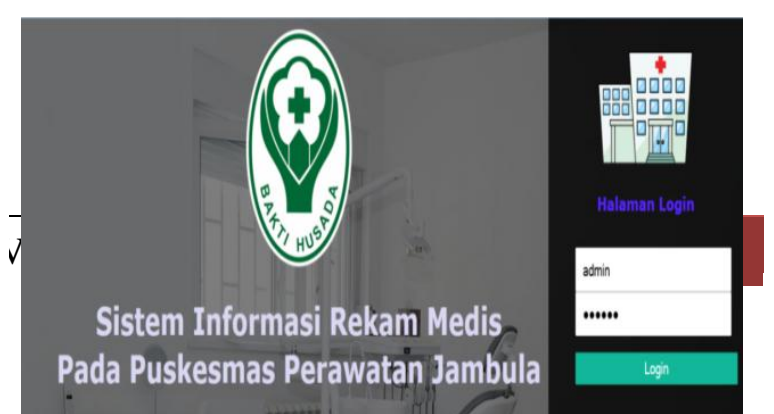


Gambar 6 : Menu Login Admin

\section{Form Data Dokter}

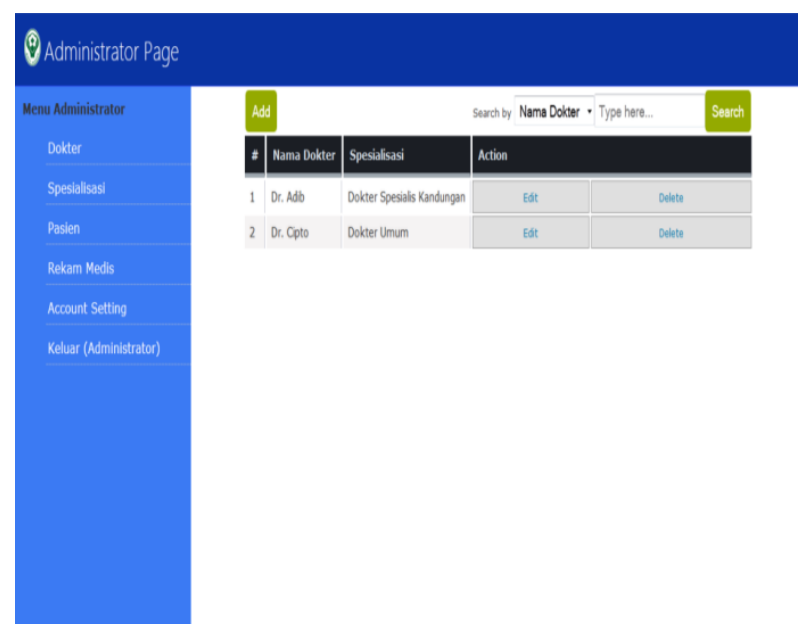

Gambar 7 : Menu Data Dokter

\section{Form data Pasien}

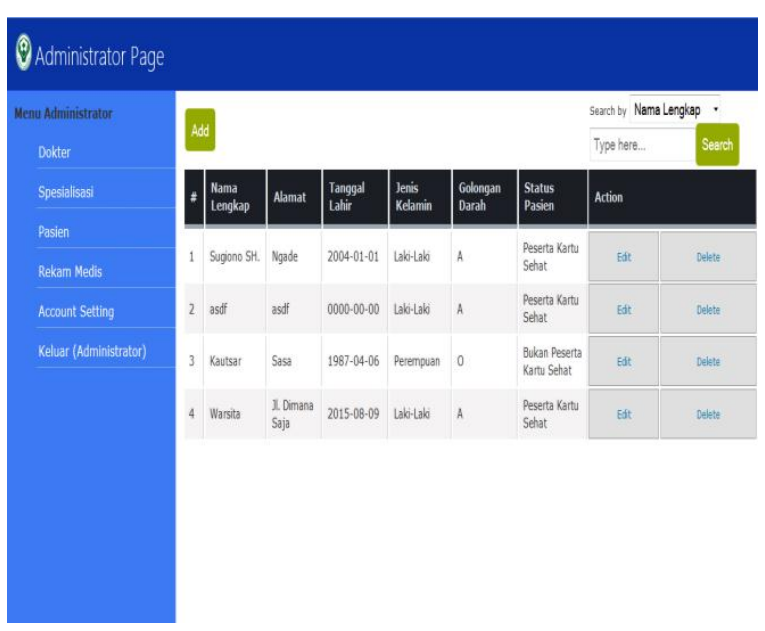

Gambar 8 : Menu Data Dokter

\section{Form Data Rekam Medis}

\section{Padministrator Page}

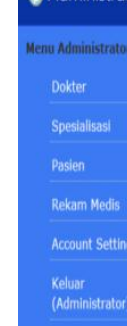

REKAM DATA MEDIS PASIEN
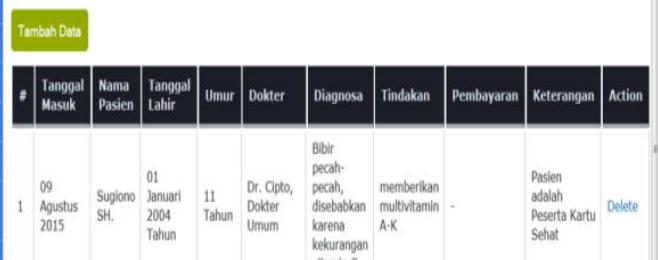

Gambar 9 : Menu Data Dokter

\section{KESIMPULAN}

Dari hasil perancangan "Sistem Pengolahan Data Rekam Medis Berbasis Web pada Puskesmas Perawatan Jambula" disimpulkan sebagai berikut :1) Sistem yang di rancang dapat memberikan kemudahan pada petugas medis dalam mengelola dan menyimpan data rekam medis pasien secara akurat dan efisien. 2) Sistem yang di buat dapat mengurangi tingkat kesalahan pada proses pencatatan data pasien secara manual.

\section{DAFTAR PUSTAKA}

Husni I. Pohan, 2002. SQL+TUTORIAL: Plus Studi Kasus dengan Oracle dan Sybase, Bandung, Penerbit Informatika

Al-Bahra. 2005. Analisis dan Desain Sistem Informasi, Yogyakarta, Penerbit Graha Ilmu

Siagian, Sondang P, 2006, Sistem Informasi Manajemen, Jakarta, Bumi Aksara..

A,Kristanto. 2007. Analisis dan Desain Sistem Informasi, Yogyakarta, Penerbit Andi.

Azhar Susanto (2007), Sistem Informasi Manajemen Konsep dan Pengembangannya. Edisi 3. Lingga Jaya. Bandung

Zaki, Ali, (2008). 36 menit belajar komputer PHPdan MySQL, Jakarta : PT Elex Media Komputindo.

Jogiyanto. (2009). Sistem Teknologi Informasi. Yogyakarta: Andi 
Nugroho, Adi. 2010. Rekayasa Perangkat Lunak Berorientasi Objek dengan metode USDP. Andi offset: Yogyakarta.

Darmawan Deni dan Permana Deden Hendra. 2013. Desain dan Pemrograman Website. PT Remaja Rosdakarya. Bandung

Endang Lestari, Ken Ditha Tania, Lailatur Rahmi, Sistem Informasi Rekam Medik Pada Rumah Sakit Bersalin Graha Rap Tanjung Balai Karimu, Jurnal Sistem Informasi (JSI), VOL. 3, NO. 2, Oktober 2011, ISSN Print : 2085-1588, ISSN Online : 23554614

Emy Budi Susilowati, Bambang Eka Purnama, Analisis Dan Perancangan Sistem Informasi Pasien Rumah Sakit Umum Nirmala Suri Sukoharjo, Indonesian Jurnal on Computer Science - Speed 12 Volume 9 No 1 - Februari 2012, ISSN 1979 - 9330

Ruslan, Aplikasi Pengolahan Data Karyawan dengan Pendekatan Microsoft Visual Basic, JURNAL SIGMATA | LPPM AMIK SIGMA Volume 2 Nomor 1 Oktober 2013 Maret 2014, ISSN 2303-5786

Azhar Irfandi, Okta Liansyah, Ervi Cofriyanti, Hermawan, Analisis dan Perancangan Sistem Informasi Akademik (Studi Kasus SMA Negeri 1 Talang Kelapa Palembang) Jatisi, Vol. 1 No. 1 September 2014, ISSN : 2407-4322

Sukadi, Abidarin Rosidi, Emha Lutfi Taufiq, Sistem Pengelolaan data Rekam Medis Di RSUD dan Puskesmas Kabupaten Pacitan, IJNS - Indonesia Journal On Networking and Security - Volume 4 No 3 - 2015
- ijns.org, ISSN 2302-5700 (Print) 2354-6654 (Online)

Thomas Afrizal, Dwi Yulistyanti, Analisis dan Perancangan Sistem Informasi Pendataan Pendidikan Kota "D”, Seminar Nasional Teknologi Informasi dan Multimedia 2015 STMIK AMIKOM Yogyakarta, 6-8 Februari 2015, ISSN : 2302-3805

Sucipto, Indah Uly Wardati, Sistem Informasi Pendaatan Pasien Pada Rumah Bersalin Dan Balai Pengobatan Pelayanan Kesejahteraan Umat (PKU) Muhammadiyah Batuwarno, IJNS Indonesian Journal on Networking and Security - Volume 4 No 2 April 2015, ISSN: 2302-5700 (Print) 2354-6654 (Online)

Muhdar Abdurahman, Sistem Informasi Jadwal Perkuliahan Berbasis Web Mobile Pada Politeknik Sains Dan Teknologi Wiratama Maluku Utara, Indonesian Journal on Networking and Security - Volume 5 No 2 - Mei 2016, ISSN : 2302-5700 (Print) 2354-6654 (Online) 